\title{
Application and effectiveness of respiratory physiotherapy in the prevention and treatment of patients with COVID-19
}

\section{Corresponding author:}

Marta Podhorecka, Collegium Medicum im. Ludwika Rydygiera, Bydgoszcz, Poland, e-mail: marta.podhorecka@ cm.umk.pl

\begin{abstract}
Introduction: COVID-19 as a respiratory disease is the latest challenge in modern medicine. As in most health problems, respiratory rehabilitation also finds application in this case.

Materials and methods: Analysis of available literature, articles in the Google Scholar and PubMed database using keywords: COVID-19, respiratory physiotherapy, lung disease, prevention, therapy. The available literature was subjectively selected, and then the latest version of each article was used.

Results: There are many physiotherapeutic methods and techniques that can be applied in the fight against COVID-19 disease, but there is still a lack of scientific research that would confirm their effectiveness in this particular disease entity. Rehabilitation of sick people, both in severe and moderate condition, should be based on airway clearance, respiratory control and adequate physical activity.

Conclusions: The issue of rehabilitation in COVID-19 disease requires further interest of researchers because there is still insufficient literature on this subject. Undeniably physiotherapy should be a significant part of the interdisciplinary approach to fight this disease entity, because the effects of its absence can significantly affect the health of patients.

Keywords: Covid-19; respiratory physiotherapy; lung disease; prevention; therapy
\end{abstract}

Med Res J 2020; 5 (4): 265-270
Medical Research Journal 2020; Volume 5, Number 4, 265-270 DOI: 10.5603/MRJ.a2020.0028 ISSN 2451-2591

\section{Introduction}

The respiratory system is currently one of the most common sources of disease, including cancer. Forecasts for the future of health risks report that the main causes of death will be, in addition to cardiovascular disease, respiratory-related diseases. Among the diseases associated with pulmonology, the most frequently mentioned are chronic obstructive pulmonary disease, lung cancer, bronchial asthma, pneumonia, and related complications [1].

At the turn of 2019 and 2020, the world began to face a new challenge to global health - Coronavirus Disease 2019. The outbreak of this virus, whose first cases were diagnosed in the Chinese province of Hubei, quickly spread around the world rising to the rank of a pandemic. The lack of individualized treatment and an effective vaccine, despite the efforts of laboratories around the world, causes the number of cases and deaths to increase worldwide [2].
Symptoms of COVID-19 appear after an incubation of about five days. The most common symptoms at the beginning of COVID-19 are fever, fatigue, and bothersome cough - which may include sputum production, hemoptysis, headache, shortness of breath, diarrhea, or lymphopenia. The clinical picture of this disease presented in the CT scan of the chest resembles the features of pneumonia, however, there were atypical features such as acute respiratory distress syndrome, acute heart damage, and the occurrence of vitreous opacities - resulting in increased inflammation and often leading to the patient's death $[2,3]$.

\section{Materials and methods}

The authors reviewed available studies and literature from sources of universal access - such as Google Scholar and PubMed - using search phrases such as COVID-19, respiratory physiotherapy, lung disease, 
prevention, and therapy. The available literature was subjected to subjective selection, and the most current version was selected from each available publication. Papers published up from October 2003 to April 31st, 2020, were included.

\section{Results}

\section{Mechanism of respiratory physiotherapy for lung} diseases

Physiotherapy plays an extremely important role in the treatment of patients with respiratory diseases. Carefully selected forms of rehabilitation, combined with proper pharmacotherapy and oxygen therapy, increase the supply of oxygen to the body. Pulmonological rehabilitation has a positive effect on the frequency of re-hospitalizations and shortening their duration, due to respiratory diseases and related complications [4].

The rehabilitation included in the holistic treatment of the pulmonological patient is aimed at optimizing the functional state, reducing the severity of symptoms, as well as increasing the involvement of the patient or in the absence of such possibility of his family and proteges [5].

The main aims of physiotherapy in pulmonology include:

- Reduction of the symptoms associated with lung diseases (shortness of breath, coughing, fatigue) and increase of breathing comfort.

- Facilitation of the treatment of respiratory dysfunction associated with insufficient ventilation in the affected areas of the lung - for example, associated with pneumonia, pneumothorax, or chest deformities.

- Restoration of a proper body posture during breathing, increase of the mobility of the chest, diaphragm, and shoulder girdle.

- Restoration of a proper breathing technique, improvement of the pulmonary ventilation, and improved usage of the respiratory reserves.

- Improvement of the muscle strength needed for optimal breathing - mainly the muscles of the chest, upper limbs, and abdomen.

- Improvement of the lung ventilation by increasing airway patency, an increase of the alveolar efficiency, removal or expansion of the bronchial secretions, or usage of the appropriate techniques for effective breathing.

- Prevention of the complications associated with insufficient lung ventilation - such as pneumonia or atelectasis.

- Improvement of the exercise tolerance by reducing respiratory work and increase of the respiratory functions [6-8].
Specific objectives depend on the individual needs of the patient resulting from the type and course of the disease (diseases) as well as his psychosocial situation and personal preferences. These may include learning how to independently use bronchial tree toilet methods, reducing disorders associated with co-morbidities (e.g. diabetes, cardiovascular disease, nervous system, and muscular diseases), obtaining positive changes in body build - such as normalization of the body weight and increase of a lean body mass - and counteracting the adverse effects of chronic corticosteroid therapy [9].

It has also been proven that exercise can reduce the severity of depression symptoms. People with severe stress reactions or high levels of mental tension (in particular the presence of panic disorder) often have an affiliation with chronic respiratory diseases. Therefore, relaxation techniques or other psychological training are often used to treat these disorders [9].

\section{Methods of pulmonary rehabilitation}

Before starting any respiratory physiotherapy methods and techniques, as well as after their completion, the patient should be thoroughly examined to individually evaluate the results of therapy and to determine the directions of further management. The basis, in this case, should be a physical examination, spirometry, exercise tolerance test, questionnaires assessing overall health, the effect of felt dyspnea, assessment of inspiratory, and expiratory muscle strength. It should be remembered that the type of treatments and the frequency of their use should be selected by a specialized physiotherapist or doctor. It is also important to choose additional exercises that the patient can perform independently (e.g. postural drainage or the use of flutter or hornet devices) $[9,10]$.

\section{Breathing exercises}

Respiratory diseases cause various dysfunctions within it, for example, in asthma, the chest tends to be set in the inspiratory position, so it is important to educate the patient about the proper use of breathing exercises. Breathing exercises should be directed at involving specific muscle groups. Examples of exercises include:

- exercises to strengthen the diaphragm,

- exercises to strengthen the external intercostal muscles,

- lower rib breathing exercises,

- abdominal strengthening exercises.

It is particularly important for the patient to acquire or restore the ability to breathe in the lower parts of the chest. Proper breathing exercises focus on deep breathing to overcome resistance. A particularly important element is exercises performed with resistance using 
various accessories from basic such as water bottles or balloons to more advanced ones, for example, Flutter apparatus, hornet, or the Voldyne Incentive Spirometer. Resistance in breathing exercises can be focused both during inspiration and exhalation. When performing breathing exercises, particular attention should be paid to disorders related to hyperventilation, which is why hourly intervals should be used and cycles should not exceed 2-3 minutes (about 8-12 inhalations or exhalations) $[9,11,12]$.

\section{Bronchial postural drainage}

Postural drainage is a type of rehabilitation for patients with difficulties in the expectoration of large amounts of bronchial secretion. The task of drainage, which means posture positions, is to remove secretions by supporting physiological mechanisms and to improve and maintain the proper lung ventilation $[9,10]$.

It involves the patient using such a position that the given section of the respiratory tract is above the lung cavity, which results in enabling the discharge of secretions accumulated in the diseased part of the lungs, as a result of gravity, from the small bronchi to the large bronchi and further into the trachea expectoration. One of the most used techniques is the Trendelenburg position in which the patient is in the supine position and the head, upper chest and torso are below the level of the lower extremities. Many other items are described, and their use depends on which lung area is occupied [9].

The bronchial positional drainage is divided into static where the secretion drains spontaneously and dynamic - with this method the patient supports the process through appropriate exercises. The procedure should be repeated several times a day, depending on the patient's condition and the number of secretions present. The duration of one static drainage treatment is from 45 minutes to an hour. The therapeutic effect of drainage can be enhanced by patting the chest or vibrating $[9,10]$.

\section{Effective coughing techniques}

Exercises for effective cough should be conducted in positions that facilitate expectoration, relieve pain, and improve lung ventilation. The technique of performing 3-4 coughs directly after each other during expiration is of great importance in this method. To improve the effectiveness of coughing, it should be intense. Exercises for effective coughing are repeated with the same frequency as breathing exercises [13,14].

Effective coughing techniques include:

- double coughing,

- reinforced coughing,

- controlled coughing,

- intensive exhalation,

- coughing combined with intensive breathing [9, 14].

\section{Patting the chest}

This method is especially used to stimulate the patient's cough and clear the bronchial tree. It usually involves patting the chest walls during the prolonged exhalation phase. It is possible to do it with one or two hands, simultaneously or alternately by a physiotherapist. The procedure is performed from the base to the top of the lung. With this technique, it is crucial to remember to avoid the kidneys and spine. The duration of the procedure is selected individually to the patient's needs $[13,14]$.

Similar rehabilitation techniques include:

- Chest spring - this method involves compressing the chest when exhaling and firmly releasing the pressure when inhaling.

- Chest vibration - for its use, special-purpose apparatus is usually used to activate secretions in the bronchial tree. Thanks to this technique, the secretion is coughed up more easily because it becomes more fluid. After the vibration procedure, it detaches from the bronchial walls and is transported to larger structures, from where it is easier to expel [15].

Other physiotherapeutic methods in respiratory diseases include:

- Physical therapy - infrared radiation, ultraviolet radiation, interference currents, short-wave diathermy, sonotherapy, and magnetotherapy.

- Massages - classic and segmental.

- Resort treatment - crenotherapy, hydrotherapy, brine, iodine, bromine, and other baths.

- Inhalations.

- Thalassotherapy $[9,16]$.

\section{Prevention in COVID-19}

Pro-health prophylaxis in COVID-19 should include the education of the patient and his/her proteges (family). It should primarily concern:

- The information about the disease and its course - with emphasis on self-assessment of breathlessness, recognition of exacerbations, and ways of responding to symptoms.

- The benefits of regular exercise and the principle of self-exercise.

- Risk factors and methods to avoid them - and ways to create a healthy lifestyle.

- Coping with the consequences of the disease (including home care, taking precautions at work, saving energy, and coping with stress).

- The patient should also be aware of undertaken therapeutic and rehabilitation activities - including breathing strategies, bronchial tree toilets, recommended medications, and methods of their use (including inhalation devices), as well as the suction of secretions $[9,11,17]$. 


\section{Physiotherapy for COVID-19 patients in the world}

Since the appearance of the first COVID-19 cases in Europe, work began on medical diagnosis and treatment schemes for infected people. SARS-CoV-2, as a member of the coronavirus family, causes severe acute respiratory distress syndrome - commonly known from the time of the SARS outbreak, which, characterized by symptoms mainly from the respiratory system, requires medical intervention in almost every case [18].

In a confrontation with the dilemma of what to do in a situation where personal medical consultation is difficult, and the daily rehabilitation centers and physiotherapeutic offices are closed, dozens of countries have encountered, starting from the Far East, Europe, and North America. National Societies of Physiotherapists responded to this unprecedented situation, because of which they issued public statements, notices, and relevant recommendations regarding both works with outpatient patients and those from hospital wards. An international discussion based on the exchange of experience, information, and opinion support was also started. As part of a cooperation between medical professions, recommendations for discussion and work in an interdisciplinary team have been made so that discussions and consultations regarding the phenomenon of SARS-CoV-2 infection can be conducted most understandably and effectively [19].

China is a pioneer in creating guidelines for physiotherapists in the treatment of people with COVID-19. This country, being the source of the first virus infections, has the richest database and information collected on the treatment and research on the virus strain. Due to the degree of SARS-CoV-2 infectivity in the report, the authors presented a specific program of respiratory rehabilitation of patients infected with the virus-based mainly on the assumption of maximizing the isolation of patients and providing patients with the possibility of autotherapy under the constant remote control of therapists, using tools such as brochures, instructional videos and remote consultations with specialists. Rehabilitation of hospital patients in both severe and moderate levels of symptoms should be based on three pillars, which include airway clearance, respiratory control, and adequate physical activity. Also, the physiotherapist is obliged to carry out antithrombotic prophylaxis, especially in lying patients and observation for psychological problems, and in critically ill patients to change the position as often as possible leading to higher positions such as reclining position [20].

Following the indications given in China, the therapy based on remote physiotherapy is also recommended by the Australian and New Zealand Intensive Care Society (ANZICS) Guidelines COVID-19, which strongly indicate the replacement of personal visits to patients and conducting procedures at Tele-Rehabilitation centers. The therapist can control the work and the course of the patient's illness using webcams and messengers. This enables both visual assessments of health conditions and continuity of rehabilitation through conducted therapy or remote learning of autotherapy. In a situation of mass quarantine, stimulating the patient to maintain maximum physical activity at home is extremely important for both the patient's physical condition and mental health [21].

This thesis also finds support in other countries. In response to the increased demand of Tele-Medicine in Canada, funds for the implementation of the Tele-Rehabilitation project under the patronage of the Canadian Association of Physiotherapists have been increased. This support is targeted mainly at people living in rural and suburban areas to facilitate their access to medical care specialists and maintain the state of the largest possible quarantine of society [22].

Also, in Poland, a document was created to specify the criteria for conduct in COVID-19 therapy and to present the principles of the professional group's operation in the fight against pandemics. Recommendations for physiotherapy for COVID -19 adult patients of March 22 ${ }^{\text {nd }}$, 2020 issued by the National Chamber of Physiotherapists under the auspices of the Association Physiotherapy Poland sets out recommendations for working with both ventilated and non-ventilated patients, and in addition to a list of appropriate selection of protection measures, gives examples of uses respiratory therapy to fight shortness of breath and when using airway clearance techniques. This document concerns the aspect of both stationary therapies of infected people and recommendations for remote consultations to maintain the greatest possible self-isolation. Importantly, attention is also paid to the need to continue physiotherapy of healers to prevent further complications in the form of impaired body function, shortness of breath, or mental disorders [23].

In turn, the Italian report addressed to physiotherapists reports that the greatest attention was paid to protective measures in contact with the patient. First of all, the isolation of the sick and the use of all available forms enabling remote contact with the patient, ranging from telephone advice to specialist video consultation, plays a key role. However, as part of the crisis in Italy, all medical professions were involved in the care of patients with COVID-19, and the rehabilitation guidelines were limited to the basic activities based on taking care of the correct positioning of the patient, frequent change of position, prevention of pressure sores and antithrombotic prophylaxis [24, 25].

Moreover, the European Respiratory Society and the European Society of Intensive Care Medicine report that among critically ill patients, physiotherapy should be based on positioning the patient's body to optimize ventilation [26].

Both in the document of China, Poland, Australia and New Zealand we can find specific studies on the 
management of patients with COVID-19 based on studies with patients suffering from SARS, which are currently the basis for the work of a physiotherapist in the context of respiratory rehabilitation with a patient with COVID-19. The current epidemiological situation requires unusual solutions, and therefore physiotherapists, apart from their daily professional practice, are encouraged to help in health care going beyond their daily competences. This activity concerns both hospital work in patient care and sharing knowledge and experience with other clinicians [19].

\section{The effectiveness of respiratory physiotherapy in the treatment of COVID-19}

Based on the observations of Italian clinicians, among the symptoms characteristic of COVID-19 patients, especially in acute condition there is both weakness of the musculoskeletal system - from reducing the range of joint mobility to critical myopathy - as well as significant respiratory problems such as retention of difficult expectorant secretions leading to inflammation or pulmonary fibrosis leading to acute respiratory failure. These symptoms make up the specific clinical picture for the course of SARS, which is why the patient's rehabilitation begins based on scientific evidence of the effectiveness of techniques and procedures in this disease unit. According to Italian clinicians, the greatest attention should be focused on preparing patients for the subacute phase of the disease - and in particular, those who came to the ICU for a long time, due to complications of long immobilization [27].

Years before the appearance of COVID-19, it has been proven that regular physical activity increases the functional reserves of organs and maintains their physiological functionality, which in the case of respiratory diseases can have a diametrical impact in the fight against disease symptoms [28, 29]. Considering the fact that the largest losses seen in complications after SARS are borne by the lungs and respiratory muscles, their activation should be started as soon as possible to maintain or improve their efficiency $[30,31]$. Besides, prolonged stay in isolation increases the risk of a decrease in immunity, by reducing the efficiency of the body due to lack of physical activity, which increases the risk of cardiovascular disease and lung disease [32].

The best source of knowledge today is the experience described after the SARS epidemic in 2002. It has been proven that patients with recovery mostly complained of a decrease in the body's efficiency, manifested by shortness of breath and rapid fatigue. The proof of the importance of respiratory rehabilitation in healthy, sick but also recovering people is the fact that as many as of the listed patients experienced breathlessness in everyday life, which resulted in deteriorated well-being. Research at the Institute of Respiratory Diseases in
Guangzhou shows both a decrease in total lung capacity and residual volume. The thesis was made that the reason for the decrease in lung efficiency was the weakening of the respiratory muscles caused by both the treatment process and long-term immobilization [30]. This history shows how important it is to implement both respiratory and general conduction physiotherapy, not only in patients but also in healthy people, because the better the functional state of the body before falling ill, the lighter the course of the disease, and consequently the smaller complications after recovery.

The case analysis of a 41-year-old patient was documented based on physiotherapy performed in COVID-19 in the intensive care unit of the SARSCoV-2 treatment center in Shenyang, China. Clinicians undertook to carry out an individualized process of patient rehabilitation based on the experience of the SARS epidemic and recommend based on the facts of the past to conduct therapy to avoid such significant complications as shortness of breath or pulmonary fibrosis [31].

Despite the many recommendations and ordinances regarding respiratory rehabilitation among patients with respiratory complaints, there is still no evidence of the effectiveness of respiratory rehabilitation among patients with COVID-19. The global situation is so dynamic that so far no information has been collected on the importance of the process of improving patients' treatment in COVID-19 treatment, and the conclusion regarding the effectiveness of therapy supporting expectoration of residual secretions in the lungs and exercises reducing the feeling of shortness of breath in patients infected with SARS-CoV-2 is based on research from SARS and MERS. The course of each of these disease entities is characterized by a specific individuality, however, in the current situation of the mass number of cases with similar clinical images to previously known diseases, one can risk the statement that using the already known evidence of the effectiveness and application of respiratory therapy in diseases caused by viruses from the coronavirus family is as rational as possible [18].

\section{Conclusions}

COVID-19 respiratory physiotherapy does not differ from the basic techniques used in the therapy of other respiratory diseases and should be based on supporting expectoration of residual secretions in the lungs and exercises reducing the feeling of breathlessness. It should be assumed that the effects of a lack of physiotherapy will bring similar complications to those after the SARS epidemic in 2002-2003, therefore every effort should be made to prevent them. As history shows, the implementation of patients' physiotherapy during illness is as important as their rehabilitation after recovery. 
At present, there is a lack of research and evidence of the effectiveness of respiratory physiotherapy on the effectiveness and rate of treatment of patients with COVID-19. It is recommended to continue the recognition subject to improve the treatment of individuals infected with SARS-CoV-2.

\section{References}

1. Kuciel-Lewandowska J, Paprocka-Borowicz M, Hawrylak A, et al Miejsce fizjoterapii w pulmonologii. Acta Bio-Optica et Informatica Medica. 2008; 4: 284-285.

2. Rothan HA, Byrareddy SN. The epidemiology and pathogenesis of coronavirus disease (COVID-19) outbreak. J Autoimmun. 2020; 109: 102433, doi: 10.1016/j.jaut.2020.102433, indexed in Pubmed: 32113704.

3. Ahn DG, Shin HJ, Kim MH, et al. Current Status of Epidemiology, Diagnosis, Therapeutics, and Vaccines for Novel Coronavirus Disease 2019 (COVID-19). J Microbiol Biotechnol. 2020; 30(3): 313-324, doi: 10.4014/jmb.2003.03011, indexed in Pubmed: 32238757.

4. Spruit MA. Pulmonary rehabilitation. European Respiratory Review. 2014; 23(131): 55-63, doi: 10.1183/09059180.00008013.

5. Olbrych A. Wpływ rehabilitacji na poprawę wydolności fizycznej ocenianej za pomocą sześciominutowego wysiłkowego testu marszowego. Medycyna Rodzinna 2018 Jan. ; 21(1): 34-38.

6. Grochans E, Bak A, Reczyńska A, et al. Ocena jakości życia chorych z przewlekłymi chorobami układu oddechowego. Probl Hig Epidemiol. 2012; 93(3): 542-545

7. Wojda E, Nowiński A, Śliwiński P. Rehabilitacja oddechowa. Przewodnik Lekarza 2007 Mar 21. ; 1: 129-133.

8. Jastrzębski D, Ziora D, Hydzik G, et al. Rehabilitacja oddechowa chorych na raka płuca. Pneumonol. Alergol. Pol. 2012 Oct; 80 ; 6: 546-554.

9. Parocka-Borowicz M, Demczyszak I, Kuciel-Lewandowska J. Fizjoteraia w chorobach układu oddechowego. Górnickie Wydawnictwo Medyczne Wrocław 2009. p 8-19. : 16-32.

10. Dylewicz P, Bromboszcz J, et al. Badanie chorego kwalifikowanego do ćwiczeń fizycznych w programie rehabilitacji kardiologicznej. In Dylewicz P., Bromboszcz J., Przywarska I., Borowicz-Bieńkowska S. Wilk M.: Rehabilitacja kardiologiczna - stosowanie ćwiczeń fizycznych. 3rd ed. Elipsa-JAIM. 2009: 195-208

11. Gębska M. Weber- Nowakowska K., Żyżniewska- Banaszak E. Zastosowanie techniki fonacyjno-oddechowo-artykulacyjnej - jako formy profilaktyki i rehabilitacji zaburzeń emisji głosu u nauczycieli. Hygeia Public Health 2014 Jan. ; 49(2): 209-214.

12. Miki K, Maekura R, Kitada S, et al. Pulmonary rehabilitation for COPD improves exercise time rather than exercise tolerance: effects and mechanisms. Int J Chron Obstruct Pulmon Dis. 2017; 12: 1061-1070 doi: 10.2147/COPD.S131061, indexed in Pubmed: 28435239.

13. Kwaśniewska A, Kamusińska E. Rola pielegniarki w rehabilitacji pacjentów po zabiegach operacyjnych w obrębie jamy brzusznej. Studia Medyczne. 2012; 25(1): 73.

14. O'Neill K, O'Donnell AE, Bradley JM. Airway clearance, mucoactive therapies and pulmonary rehabilitation in bronchiectasis. Respirology. 2019; 24(3): 227-237, doi: 10.1111/resp.13459, indexed in Pubmed: 30650472

15. Wnuk D, Hansdorfer-Korzon R, Żuralska-Wnuk J, et al. Postępowanie fizjoterapeutyczne u pacjentów po zabiegu resekcji miąższu płuca. Pneumonologia i Alergologia Polska. 2013; 82(1): 46-54, doi 10.5603/piap.2014.0008.

16. Hupa M, Orczyk M, Baryła A, et al. Wpływ rehabilitacji pulmonologiczne na stan pacjentów z astma oskrzelową. Fizjoterapia Oddechowa. 2015: 24-27.
17. Rutkowski R, Rutkowska A, Rutkowski K, et al. Wybrane zagadnienia rehabilitacji oddechowej. Fizjoterapia Polska 2009; 1(4); vol. ; 9: 21-30.

18. Yin $Y$, Wunderink RG. MERS, SARS and other coronaviruses as causes of pneumonia. Respirology. 2018; 23(2): 130-137, doi: 10.1111/resp.13196, indexed in Pubmed: 29052924

19. Haines KJ, Berney S. Physiotherapists during COVID-19: usual business, in unusual times. J Physiother. 2020; 66(2): 67-69, doi: 10.1016/j. phys.2020.03.012, indexed in Pubmed: 32291227

20. Chinese Association of Rehabilitation Medicine, Respiratory Rehabilitation Committee of Chinese Association of Rehabilitation Medicine, Cardiopulmonary Rehabilitation Group of Chinese Society of Physical Medicine and Rehabilitation. [Recommendations for respiratory rehabilitation of coronavirus disease 2019 in adult]. Zhonghua Jie He He Hu Xi Za Zhi. 2020; 43(4): 308-314, doi: 10.3760/cmaj.cn112147-20200228-00206, indexed in Pubmed: 32294814

21. Melbourne: ANZICS, ANZICS COVID-19 Guidelines. https://www. anzics.com.au/wp-content/uploads/2020/03/ANZICS-COVID-19-Guidelines-Version-1.pdf (2020 Apr 28)

22. Canadian Physiotherapy Association; The CPA's Position on Tele-Rehabilitation; c2020. https://physiotherapy.ca/cpas-position-tele-rehabilitation (2020 Apr 28)

23. Cieloszczyk A., Lewko A., Śliwińska A., Włoch T., Pyszora A., Koronawirus SARS-COV-2 Zalecenia do prowadzenia fizjoterapii dorosłych pacjentów z COVID-19. https://kif.info.pl/file/2020/03/Zalecenia-doprowadzenia-fizjoterapii-doros\%C5\%82ych-pacjento\%CC\%81w-zCOVID-19-1.pdf (2020 Apr 28).

24. De l'Associazione Riabilitatori dell'Insufficienza Respiratoria, en collaboration avec I'Associazione Italiana Fisioterapisti, Indicazioni per la fisioterapia respiratoria in pazienti con infezione da COVID-19; c2020. https://aifi.net/wp-content/uploads/2020/03/Indicazioni-per-fisioterapiarespiratoria-in-COVID19-agg-16-03-2020.pdf (2020 Apr 28).

25. Nota congiunta AIFI - Commissioni di Albo dei Fisioterapisti, Note Sulla Rimodulazione Degli Interventi Fisioterapici in Relazione All'emergenza COVID19; c2020. https://aifi.net/wp-content/uploads/2020/03/nota12-marzo-2020-COVID19-per-fisioterapisti-congiunto-AIFI-CDAOrdiniTSRMPSTRP.pdf ( 2020 Apr 28)

26. Gosselink R, Bott J, Johnson M et al. Physiotherapy for adult patients with critical illness: recommendations of the European Respiratory Society and European Society of Intensive Care Medicine Task Force on Physiotherapy for Critically III Patients. Intensive Care Med. 2008; 34(7): 1188-1199, doi: 10.1007/s00134-008-1026-7, indexed in Pubmed: 18283429

27. Kiekens C, Boldrini P, Andreoli A, et al. Rehabilitation and respiratory management in the acute and early post-acute phase. „Instant paper from the field" on rehabilitation answers to the COVID-19 emergency. Eur J Phys Rehabil Med. 2020; 56(3): 323-326, doi: 10.23736/S19739087.20.06305-4, indexed in Pubmed: 32293817.

28. Jiménez-Pavón D, Carbonell-Baeza A, Lavie CJ. Physical exercise as therapy to fight against the mental and physical consequences of COVID-19 quarantine: Special focus in older people. Prog Cardiovasc Dis. 2020 [Epub ahead of print], doi: 10.1016/j.pcad.2020.03.009, indexed in Pubmed: 32220590

29. Lavie CJ, Ozemek C, Carbone S, et al Sedentary Behavior, Exercise, and Cardiovascular Health. Circ Res. 2019; 124(5): 799-815, doi: 10.1161/CIRCRESAHA.118.312669, indexed in Pubmed: 30817262.

30. CHAN KS, ZHENG JP, Mok YW, et al. SARS: prognosis, outcome and sequelae. Respirology. 2003; 8(s1): S36-S40, doi: 10.1046/j.1440$-1843.2003 .00522 . x$

31. Zhu C, Wu Y, Liu H, et al. Early pulmonary rehabilitation for SARSCoV-2 pneumonia: Experience from an intensive care unit outside of the Hubei province in China. Heart Lung. 2020 [Epub ahead of print], doi: 10.1016/j.hrtlng.2020.04.007, indexed in Pubmed: 32312554.

32. Chen P, Mao L, Nassis GP, et al. Coronavirus disease (COVID-19): The need to maintain regular physical activity while taking precautions. $J$ Sport Health Sci. 2020; 9(2): 103-104, doi: 10.1016/j.jshs.2020.02.001, indexed in Pubmed: 32099716. 